\title{
Mapping temporal changes in landscape spatial heterogeneity using the contrast weighted edge density index
}

\author{
Özdemir Şentürk ${ }^{\mathrm{a}, *}$, İbrahim Özdemir
}

\begin{abstract}
The aim of this study is to map and analyze the temporal changes in the landscape structural heterogeneity over the past 40 years in a brutian pine (Pinus brutia Ten.) dominated forest area in the Mediterranean region of Turkey. The change detection analysis was done based on two forest stand maps belonging to 1966 and 2006 years. We used the Contrast Weighted Edge Density Index (CWEDI) for quantifying landscape structural heterogeneity. The study area was converted to $500 \times 500 \mathrm{~m}$ grid cells and then a CWEDI value was calculated for each cell. The temporal differences were determined by subtracting the cell values in the heterogeneity map of 2006 year from the corresponding cell values in the map of 1966 year. In the change map, we perceived that the changes in $24 \%$ of the area (2364.93 ha) resulted from the management activities. The changes in the rest of study area (7471.75 ha) might occur due to other factors except management activities such as the natural growth in the stands or the photo-interpretation differences between the two measurement times. The study results show that the even-aged management has promoted the artificial edges between brutian pine stands with different ages while it has reduced the natural edges. Although the patchiness generated by the wood-oriented management may positively affect edge-dwelling species, it may have negatively influences on edge-sensitive species. As a result, a biodiversity-friendly forest management strategy should be developed to maintain a good balance between wood production and non-wood forest values in the brutian forests.
\end{abstract}

Keywords: Edge, Brutian pine, Patch, Contrast weighted edge density index

\section{Zıtlığa dayalı kenar yoğunluk indeksi kullanılarak arazinin mekânsal heterojenliğindeki zamansal değişimin haritalanması}

\begin{abstract}
Özet: Bu çalışmanın amacı, Akdeniz Bölgesi’ndeki kızılçam (Pinus brutia Ten.) ormanlarında son 40 yılda meydana gelen yapısal heterojenliğin zamansal değişimlerini haritalamak ve analiz etmektedir. Değiş̧ikliklerin tespit edilmesinde 1966 ve 2006 yıllarına ait meşcere tipleri haritaları esas alınmıştır. Arazinin yapısal heterojenliğini ölçmek için Zıtlığa Dayalı Kenar Yoğunluk İndeksi (CWEDI) kullanılmıștır. Calıșma alanı 500 x $500 \mathrm{~m}$ grid hücrelere bölünmüs ve daha sonra her hücre için bir CWEDI değeri hesaplanmıştır. Zamansal farklılıklar, 2006 yılındaki heterojenlik haritasındaki hücre değerlerinin 1966 yılı haritasındaki hücre değerlerinden çıkarılmasıyla elde edilmiştir. Elde edilen haritada, bölgenin \%24'ünde meydana gelen değișikliklerin ( 2364.93 ha) yönetim faaliyetlerinden kaynaklandığı görülmüştür. Çalışma alanının geriye kalan kısmında (7471.75 ha) meydana gelen değişiklikler, meşcerelerdeki doğal büyüme ya da iki zaman ölçüm zamanı arasındaki foto-yorum farkları gibi yönetim faaliyetleri dışındaki diğer faktörlerden kaynaklanmıştır. Çalışma, eski planların, doğal kenarları azaltarak, farklı yaşlı kızılçam meşcereleri arasındaki yapay kenarları desteklediğini göstermektedir. Odun üretimi odaklı yönetim planlarının meydana getirdiği parçalar, kenarda yaşayan türleri olumlu yönde etkilesede kenara duyarlı türleri olumsuz etkileyebilir. Sonuç olarak, kızılçam ormanlardaki odun üretimi ve odun dışı orman ürünleri arasında iyi bir denge sağlamak için biyoçeşitlilik dostu bir orman yönetimi stratejisi geliştirilmelidir.

Anahtar kelimeler: Kenar, Kızılçam, Yama, Zıtlığa dayalı kenar yoğunluk indeksi
\end{abstract}

\section{Introduction}

The spatial structure of forest landscapes is associated with the composition and configuration of landscape patches and is usually accepted as a key factor in biodiversity management (Lindenmayer et al. 2012; Tscharntke et al. 2012; Matte et al. 2015). A high complexity in the landscape structure often provides foraging, breeding, and hiding habitats for various wildlife species (Fahrig et al. 2011; Mert and Yalcinkaya, 2017). Landscape structure attributes have changed through time by both management activities including regeneration, reforestation, rehabilitation and destructive factors such as fire, insect attack, windstorm, conversion to agriculture and illegal harvesting (Hansson et al. 2012). Monitoring these changes by definite time intervals and taking necessary precautions is vital for sustainable management of forest ecosystems. Particularly, landscape structure is negatively affected by wood oriented management system (Paillet et al. 2010). Traditional evenaged management constitutes homogeneous stands that form a structurally simple landscape. Therefore, analysing the effects of existing management activities on the Landscape Structural Heterogeneity (LSH) is very important to develop an appropriate management system for biodiversity conservation. This examination should be particularly

\footnotetext{
$\square$ a Burdur Mehmet Akif Ersoy Üniversitesi, Gölhisar Meslek Yüksekokulu, Ormancılık Bölümü, Burdur

b Isparta Uygulamalı Bilimler Üniversitesi, Orman Fakültesi, Yaban Hayatı Ekolojisi ve Yönetimi Bölümü, Isparta 
considered in conifer-dominated forests where even-aged system is widely practiced.

The brutian pine forests (Pinus brutia Ten.) that play an important role in the industrial round-wood production in Turkey are a typical example of even-aged management system. They approximately cover an area of 5.9 million ha (GDF, 2013) and have been intensively managed approximately for half a century. The second-growth stands of brutian pine covering extensive areas have lead to a relatively homogeneous landscape over this period. Furthermore, the vertical structure of these stands has become simpler than native stands mainly due to regular tending and felling made for improving the wood quality. Consequently, the biodiversity might be negatively affected in these forested landscapes. In addition to the regeneration, the cultivated plantation stands established by planting of the shrub cover have been expanded in order to increase the amount of commercial brutian pine areas. However, the shrub cover is considered vital for biodiversity conservation in the Mediterranean region because its high species diversity may provide a unique habitat for shrub-dwelling species. Because of these reasons, a study is urgently required in a representative landscape consisting mainly of brutian pine stands in order to understand the influences of existing management system on horizontal forest structure.

Temporal forest maps are very useful resources to track the changes in landscape structure, and they have been widely used in many studies (e.g. De Groot et al. 2010; Wang et al. 2010). The landscape metrics such as Shannon Diversity Index, Interspersion and Juxtaposition Index, Simpson Diversity Index, and Edge Density Index (Walz, 2011; Šímová and Gdulová, 2012) which are generated using Geographic Information System (GIS) are employed to describe the landscape spatial heterogeneity. It is possible to compare temporal forest maps by means of landscape metrics in terms of spatial heterogeneity (Kelly et al. 2011; Plexida et al. 2014). Most studies analyzed changes for whole landscape level (e.g. mean patch size) and did not yield a spatial data product indicating the position of changes in spatial heterogeneity (De Groot et al. 2010; Ode et al. 2010; Verburg et al. 2011; Lausch et al. 2015). However, the changes in structural diversity should be localised and mapped to better understand the impacts of management activities or other devastating factors spatially. Therefore, the required silvicultural treatments can be determined using these spatial change detection maps for biodiversity conservation.

The aim of this study was to determine and map the temporal changes in the landscape structural heterogeneity over the past 40 years in a brutian pine dominated forest area. The reasons of the changes are discussed and the suggestions are given to conserve biodiversity.

\section{Material and Methods}

\subsection{Study area}

A forested landscape located in the Aşağıgökdere Forest Planning Unit in Isparta Forest Regional Directorate of Forestry was chosen as a study area, as the forests there have been intensively managed for about 40 years. The major land cover type is brutian pine stands in different successional stages in the study area. The Juniper (Juniperus communis L.) and Oak (Quercus sp.) stands covering small areas are also present in the landscape. Oriental Plane (Platanus orientalis L.) and Taurus Alder (Alnus glutinosa L. supsp. antitaurica) compose stands along riparian zones. Shrub areas as a typical component of Mediterranean landscapes are found at this site. The study are $\left(37^{\circ} 50^{\prime} 12^{\prime \prime}\right.$ $-37^{\circ} 59^{\prime} 76^{\prime \prime} \mathrm{N} ; 30^{\circ} 80^{\prime} 12^{\prime \prime}-30^{\circ} 87^{\prime} 58^{\prime \prime} \mathrm{E}$ ) is located at an elevation of between $290-1445 \mathrm{~m}$ above sea level. In the district, the annual average temperature is $13.6^{\circ} \mathrm{C}$ and the yearly average total precipitation is $340 \mathrm{~mm}$. The district is characterized by different parent materials, but it is mostly limestone.

\subsection{The forest maps}

We used two forest stand maps of Aşağıgökdere Forest Planning Unit belonging to 1966 and 2006 years for the comparison. Initially, landscape patches were defined by merging the existing forest stand types classified beforehand for timber management. The generated 14 main land cover categories (patches) using GIS, which are: i) Brutian pine stands in tree stage and with a canopy closure of $10-40 \%$, ii) Brutian pine stands in tree stage and with a canopy closure of $41-70 \%$, iii) Brutian pine stands in tree stage and with a canopy closure of $>70 \%$, iv) Brutian pine stands in pole stage and with a canopy closure of $10-40 \%, v$ ) Brutian pine stands in pole stage and with a canopy closure of $41-70 \%$, vi) Brutian pine stands in pole stage and with a canopy closure of $>70 \%$, vii) Open Juniper stands with a canopy closure of $<10 \%$, viii) Open Brutian pine stands with a canopy closure of $<10 \%, i x$ ) Open Oak stands with a canopy closure of $<10 \%, x$ ) Mixed stands with a normal canopy closure of $>\% 70, x i$ ) Shrub and grass openings, xii) Brutian pine stands in thicket stage, xiii) Recent clear-cut, and xiv) Agricultural areas.

\subsection{Methodology}

In order to make a reliable comparison between different land cover maps, structural diversity of landscape should be quantified by means of landscape metrics (Walz, 2011; Símová and Gdulová, 2012). Landscape metrics are algorithms for quantifying spatial heterogeneity. They are easy to use and less expensive than extensive surveys in the evaluation of landscape pattern. There are a number of landscape metrics; however, some of them are highly correlated with each other. In this study, we employed the Contrast Weighted Edge Density Index (CWEDI) for quantifying landscape structural heterogeneity as the amount of edge in a landscape is directly related to the degree of spatial heterogeneity in that landscape (McGarigal et al. 2002).

If patch edge density is high, it implies greater spatial heterogeneity (McGarigal et al. 2002). It is a straightforward metric and widely used in the works regarding wildlife ecology as the edges in a landscape are accepted vital for edge - dwelling species (Ries and Sisk, 2010; Crooks et al. 2011). Edge density index value is calculated by dividing total edge length of a unit by the area of that unit. This index only takes into consideration the length of edges; though, the characteristics of patches forming the edges are ignored. Yet, the quality of an edge for wildlife is directly related to the contrast between the patches. Therefore, the CWEDI as a more powerful metric should be preferred. The CWEDI takes into account the edge contrast, in which the length of 
edges is multiplying by weight factors describing contrast between patches forming that edge. The CWEDI, in this way, attempts to quantify edge from the perspective of its functional significance (McGarigal et al. 2002). The formula (1) of this index is:

$$
C W E D I=\frac{\sum_{k=1}^{m}\left(e_{i k}^{*} d_{i k}\right)}{A} \times(10000)
$$

Where; $e_{i k}$ is total length (m) of edge in landscape between patch types (classes) $i$ and $k ; d_{i k}$ is dissimilarity (edge contrast weight) between patch types $i$ and $k$; $A$ is total landscape area $\left(\mathrm{m}^{2}\right)$ (McGarigal et al. 2002).

The usefulness of CWEDI is directly related to the meaningfulness of the weighting values used to quantify edge contrast. However, there is not a strong quantitative basis for establishing a weighting scheme (McGarigal, 2001). The patch structural attributes such as basal area, tree volume, density and number of trees were not feasible alone to describe the contrast of edges between the all patches. The floristic characteristics of patches should also be considered. Thus, in this study, we assigned scores from 1 to 10 for all possible edges taking into account both structural and floristic contrast between adjacent patches (Table 1). Consequently, we weighted edges somewhat subjectively, but this approach was probably better than assuming all edges are alike (McGarigal et al. 2002). Two examples regarding the score of contrast weight are given in Figure 1.

In order to generate a wall to wall map to describe structural diversity, the study area was converted to grid cells and then a CWEDI was calculated for each cell (Figure 2). This approach is widely used in mapping of Habitat Suitability or Recreation Suitability (Weyland and Laterra, 2014). However, there is not definite information about cell size of grid in literature. Various cell sizes have been used according to the nature of the phenomenon under consideration and ecological conditions of study site. In this study, the cell size was determined taking into consideration the shapes and magnitude of landscape patches. A 25 ha $(500 \times 500 \mathrm{~m})$ cell size was found to sufficiently capture the structural heterogeneity. Consequently, a map based on CWEDI was generated; each cell of this map holds a numeric value of heterogeneity. The temporal differences were determined by subtracting the cell values in the heterogeneity map of 2006 year from the corresponding cell values in the map of 1966 year. As a result of this cell to cell comparison, a change map was generated that showed the rates of increase and decrease in structural heterogeneity (Figure 3).
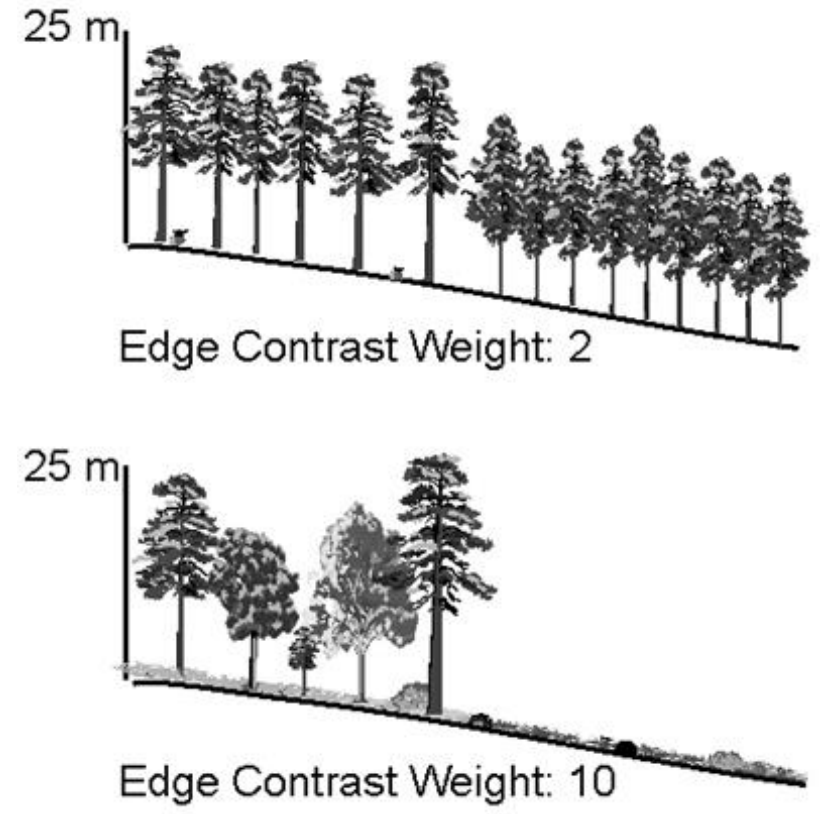

Figure 1. Two examples of high and low edge contrast weights. The edge above is between a Brutian pine stands in tree stage and with a canopy closure of $>71 \%$ and a Brutian pine stands in pole stage and with a canopy closure of $>71 \%$; The edge below is between a Mixed stands with a normal canopy closure of $>\% 71$ and a opening area

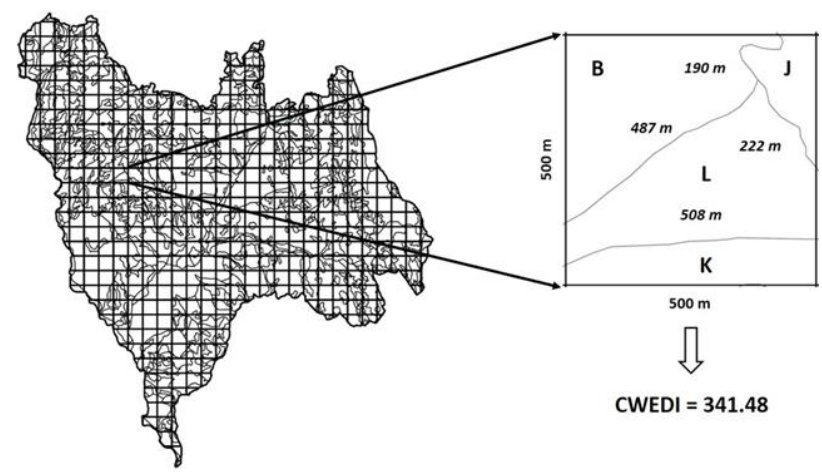

Figure 2. An example of the calculation of the CWEDI value of a cell of 25 ha. 
Table 1. The contrast values for the edges among the patches

\begin{tabular}{|c|c|c|c|c|c|c|c|c|c|c|c|c|c|c|}
\hline Patch types & $\mathrm{A}$ & $\mathrm{B}$ & $\mathrm{C}$ & $\mathrm{D}$ & $E$ & $\mathrm{~F}$ & $\mathrm{G}$ & $\mathrm{H}$ & I & $\mathrm{J}$ & $\mathrm{K}$ & $\mathrm{L}$ & $\mathrm{M}$ & $\mathrm{N}$ \\
\hline A & - & & & & & & & & & & & & & \\
\hline $\mathrm{B}$ & 1 & - & & & & & & & & & & & & \\
\hline $\mathrm{C}$ & 1 & 3 & - & & & & & & & & & & & \\
\hline $\mathrm{D}$ & 2 & 5 & 5 & - & & & & & & & & & & \\
\hline $\mathrm{E}$ & 3 & 2 & 4 & 1 & - & & & & & & & & & \\
\hline $\mathrm{F}$ & 3 & 4 & 2 & 1 & 1 & - & & & & & & & & \\
\hline G & 4 & 7 & 7 & 3 & 6 & 6 & - & & & & & & & \\
\hline $\mathrm{H}$ & 1 & 7 & 7 & 3 & 6 & 6 & 2 & - & & & & & & \\
\hline I & 6 & 7 & 7 & 3 & 6 & 6 & 5 & 5 & - & & & & & \\
\hline $\mathrm{J}$ & 7 & 6 & 6 & 7 & 7 & 7 & 8 & 8 & 8 & - & & & & \\
\hline $\mathrm{K}$ & 10 & 10 & 10 & 9 & 9 & 9 & 7 & 7 & 7 & 10 & - & & & \\
\hline $\mathrm{L}$ & 9 & 9 & 9 & 8 & 8 & 8 & 6 & 6 & 6 & 9 & 2 & - & & \\
\hline M & 6 & 7 & 7 & 3 & 6 & 6 & 5 & 5 & 1 & 8 & 7 & 6 & - & \\
\hline $\mathrm{N}$ & 10 & 10 & 10 & 9 & 9 & 9 & 7 & 7 & 7 & 10 & 1 & 1 & 7 & - \\
\hline
\end{tabular}

A) Brutian pine stands in tree stage and with a canopy closure of 10-40\%, B) Brutian pine stands in tree stage and with a canopy closure of 41-70\%,

C) Brutian pine stands in tree stage and with a canopy closure of $>71 \%$, D) Brutian pine stands in pole stage and with a canopy closure of $10-40 \%$,

E) Brutian pine stands in pole stage and with a canopy closure of $41-70 \%$, F) Brutian pine stands in pole stage and with a canopy closure of $>71 \%$,

G) Open Juniper stands with a canopy closure of $<10 \%, \mathrm{H}$ ) Open Brutian pine stands with a canopy closure of <10\%, I) Open Oak stands with a canopy closure of $<10 \%$, J) Mixed stands with a normal canopy closure of $>\% 71$, K) Shrub and grass openings, L) Brutian pine stands in thicket stage, M) Recent clear-cut, N) Agricultural areas.

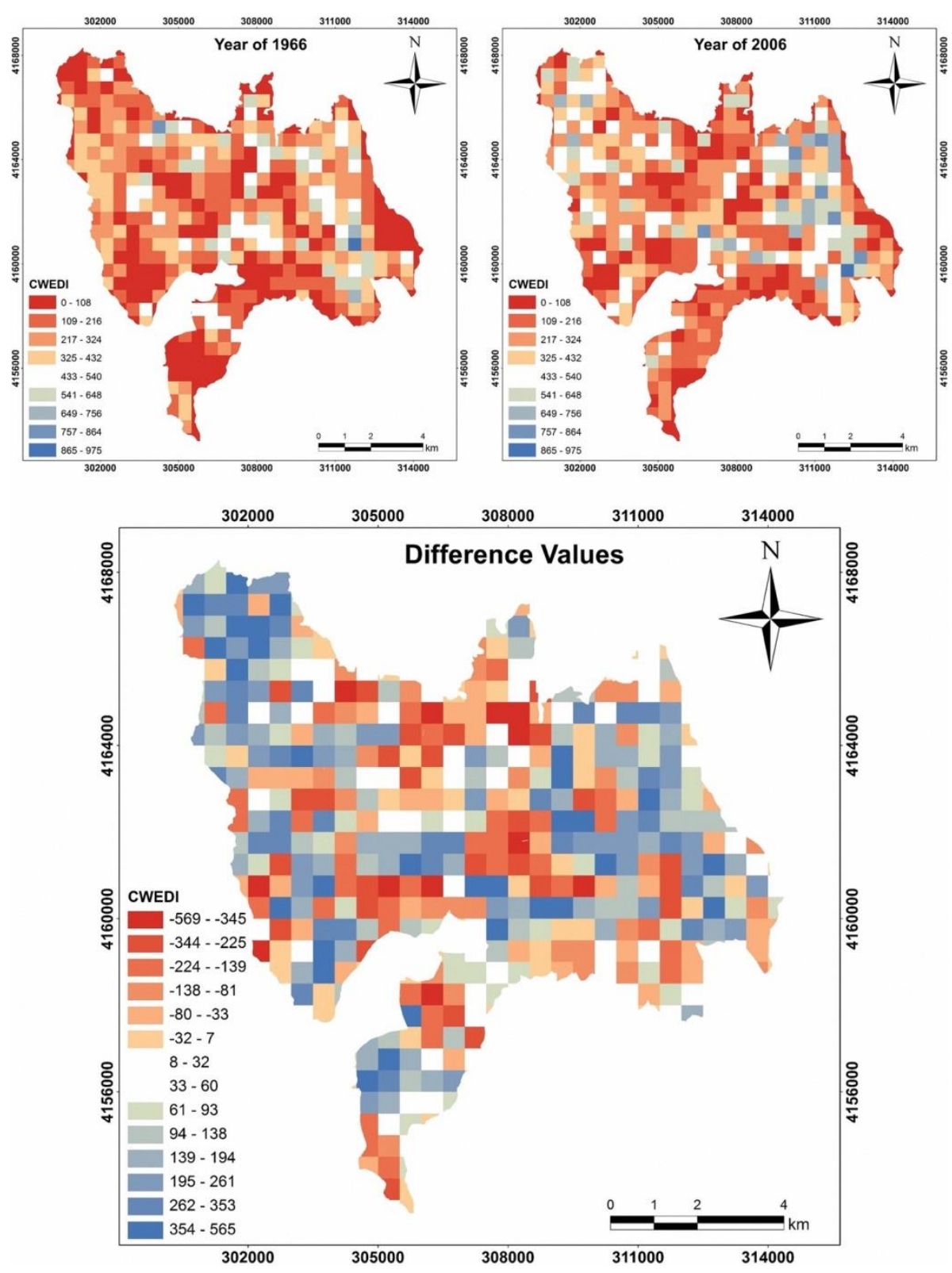

Figure 3. The CWEDI-based heterogeneity maps of 1966 and 2006 years and the change map 


\section{Results and discussion}

The CWEDI-based heterogeneity maps of 1966 and 2006 years and the change map prepared in accordance with the differences between cell values belonging to these years were given in Figure 3. In the heterogeneity maps, the index values were scaled to 256 ( 0 and 255 ) grey levels; therefore, the bright cells indicate a high structural heterogeneity while the dark cells show a low structural heterogeneity. In the change map, the blue colour tones show the cells with positive values in which the spatial structural heterogeneity has increased, while the red colour tones indicates the opposite.

The change detection map shows that the structural diversity increased in $63 \%$ (i.e. $6154.27 \mathrm{ha}$ ) and decreased in $37 \%$ (i.e. 3682.41 ha) of the total area over 40 years period between 1966 and 2006. These areas were calculated according to the number of cells having the negative and positive differences. However, the small changes may be ignored as we noticed that $76 \%$ (7471.75 ha) of the total area had the CWEDI values between -246 and +246 that have not been usually regenerated or reforested in the past. These limited alterations occurred between 1966 and 2006 might be due to the other factors such as the growth in the stands or the photo-interpretation differences between the two time periods. Therefore, in order to assess of the effects of management activities very well, we focused on the highly changed areas with deep colours of red and blue in the map.

The results show that the spatial heterogeneity has increased because the area where the CWEDI values are evidently increased (1586.42 ha, 16\%) is approximately two times larger than the area where the CWEDI values are evidently decreased (778.51 ha, $8 \%)$. The reduction in mean patch size from 0.28 ha to 0.16 ha also indicates that the patchiness has increased the planning unit. In examining the area where the spatial structural heterogeneity has drastically increased, we recognized that the contiguous old growth stands covering large areas have been regenerated resulting in the small patches of thicket or pole stage stands. Consequently, the harvest/regeneration activities under even-aged management have increased the edge density in the old growth pure stands of brutian pine in the map of 1966 year. In the early stages, the edges between regeneration areas and old growth stands may provide a foraging and hiding habitat for some mammals such as deer and rabbit (Cardinal et al. 2012). However, after the crown closure occurs in the regeneration area, these habitat features in the edges disappear. In conclusion, the increase in patchiness is not desired for wildlife as the edge contrast is low between the brutian pine stands with different seral (successional) stages.

When investigating the areas where spatial heterogeneity has decreased, we recognize that the decrease is due mainly to two reasons: regeneration and reforestation practices. In contrast to the effects of the regeneration practices on the pure old growth stands, the regeneration has sometimes decreased the spatial heterogeneity in the landscape having a mix of small patches of the other tree species, shrub and grass openings. Principally, these small patches are artificially re-vegetated by brutian pine and merged with the naturally regenerating areas in order to form a large and pure stand block suitable for wood production. In addition to this, the degraded forest stands and shrub covers over large areas have been planted to increase productive brutian forest areas. Therefore, the functional edges having a high contrast in the past disappeared between 1966 and 2006 in these areas.

This study shows that the large amount of contiguous old growth forests have been transformed into a mosaic of different seral stages by the management activities over the past 40 years. Consequently, the even-aged management has promoted the artificial edges between brutian pine stands with different ages while it reduced the natural edges. Therefore, the patchiness here has been mostly generated by the second-growth brutian pine stands regenerating after clear-cut. The patchiness may have a variety of effects on wildlife. It may be beneficial for edge-dwelling species in the early seral stages. Many studies reported that the edges between mature stands and clear cut areas provide forage and escape cover for the different species of deer and rabbits (Morrison et al. 2012; Kamieniarz et al. 2013). Therefore the predators such as the eagle, owl, and the lynx often concentrate their hunting activities near edges because of the abundance and diversity of prey animals that are attracted to this special habitat. In contrast, some edgesensitive species shun edges and prefer the interior of large habitat block to make a defence against edge-roaming predators (Š́álek et al. 2010; Mert and Yalcinkaya, 2016). Consequently forest manager should consider both improving the positive impacts of clear cut as well as lessen the devastating impacts of it on edge-sensitive species.

Producing high timber volumes is still a management goal in Turkey. Therefore, a biodiversity-friendly forest management strategy should be developed that maintains a good balance between wood production and non-wood forest values and services. The close to nature forest silvicultural practices can be used for this purpose. Firstly, timber cuts can be made to approximate natural gaps created by the disturbance factors such as windstorm, fire and insect attack. Small and irregularly shaped croups (with large perimeter-to-area ratios) similar to natural gaps should be used instead for extensive clear-cut areas and they should be evenly dispersed over landscape to increase the amount of edges. The percentage of the landscape remaining in mature forest and its connectivity are important consideration in biodiversity management (Drummond and Loveland, 2010). Secondly, an amount of old growth forests remnants and shrub covers having a sufficient core size should be left intact; particularly in the unproductive sites for wood production or the steeper areas with high erosion risk. Besides, strips of mature forest known as "greenbelt" can be maintained among clear-cut blocks. Thus, connectivity can be established by these corridors among the mature stands and maquis areas in the forest matrix. Also, the connectivity in the landscape matrix may be improved by green tree retention reducing the isolating effects of clear-cut areas. Lastly, the fruit shrub species including Rosa sp., Ceratonia siliqua L., Crataegus sp., and Pyrus sp. should also be planted along the boundaries of clear-cut areas to enhance the edge effect for wild animals. 


\section{Conclusions}

Recognition and understanding of the impacts of historical management activities help forest managers to decide on the best management options for their forest lands. The historical forest maps in archive are excellent data source for this evaluation. This study revealed that the GIS-based approach based on the contrast weighted edge density index (CWEDI) seems an excellent tool in monitoring spatial heterogeneity at landscape scale. In conclusion, the even-aged management applied over 40 years in brutian pine forests temporary increased landscape heterogeneity because of recently regenerated blocks. However, this management system decreased the mature or late-successional stands contained patches of scattered grass or shrub openings. Therefore, it generates more homogeneous forest landscapes in the long term. The question raised in this work is to determine the sufficient size of grid cells for reasonable mapping of landscape structural heterogeneity. In further studies, a set of cell sizes should be tested to decide the best one for this purpose. The other landscape metrics should also be experimented in any further study.

\section{Acknowledgement}

This article is drived from the Master Thesis by Özdemir Şentürk. We thank to Süleyman Demirel University Scientific Research Projects Coordination Unit (SDÜ BAP) for providing financial support to the thesis as a project (No: BAPKB-1644-YL-08).

\section{References}

Cardinal, E., Martin, J.L., Tremblay, J.P., Côté, S. D., 2012. An experimental study of how variation in deer density affects vegetation and songbird assemblages of recently harvested boreal forests. Canadian Journal of Zoology, 90(6): 704-713.

Crooks, K.R., Burdett, C.L., Theobald, D.M., Rondinini, C., Boitani, L., 2011. Global patterns of fragmentation and connectivity of mammalian carnivore habitat. Philosophical Transactions of the Royal Society B: Biological Sciences, 366(1578): 2642-2651.

De Groot, R.S., Alkemade, R., Braat, L., Hein, L., Willemen, L., 2010. Challenges in integrating the concept of ecosystem services and values in landscape planning, management and decision making. Ecological complexity, 7(3): 260-272.

Drummond, M.A., Loveland, T.R., 2010. Land-use pressure and a transition to forest-cover loss in the eastern United States. BioScience, 60(4): 286-298.

Fahrig, L., Baudry, J., Brotons, L., Burel, F.G., Crist, T.O., Fuller, R.J., Sirami, C., Siriwardena, G.M., Martin, J.L., 2011. Functional landscape heterogeneity and animal biodiversity in agricultural landscapes. Ecology letters, 14(2): 101-112.

GDF, 2013. Forest Atlas. Republic of Turkey Ministry of Forestry And Water Affairs, Genaral Directorate of Forestry. http://www.ogm.gov.tr/ekutuphane/Yayinlar/ Orman\%20Atlasi.pdf. Accessed: 11.12.2018.

Hansson, L., Fahrig, L., Merriam, G., (Eds.) 2012. Mosaic landscapes and ecological processes. Springer Science \& Business Media.
Kamieniarz, R., Voigt, U., Panek, M., Strauss, E., Niewęgłowski, H., 2013. The effect of landscape structure on the distribution of brown hare Lepus europaeus in farmlands of Germany and Poland. Acta theriologica, 58(1): 39-46.

Kelly, M., Tuxen, K.A., Stralberg, D., 2011. Mapping changes to vegetation pattern in a restoring wetland: Finding pattern metrics that are consistent across spatial scale and time. Ecological Indicators, 11(2): 263-273.

Lausch, A., Blaschke, T., Haase, D., Herzog, F., Syrbe, R.U., Tischendorf, L., Walz, U., 2015. Understanding and quantifying landscape structure-A review on relevant process characteristics, data models and landscape metrics. Ecological Modelling, 295: 31-41.

Lindenmayer, D.B., Franklin, J.F., Lõhmus, A., Baker, S.C., Bauhus, J., Beese, W., Brodie, A., Kiehl, B., Kouki, J., Martínez Pastur, G., Messier, C., Neyland, M., Palik, B., Sverdrup-Thygeson, A., Volney, J., Wayne, A., Gustafsson, L., 2012. A major shift to the retention approach for forestry can help resolve some global forest sustainability issues. Conservation Letters, 5(6): 421-431.

Matte, A.L.L., Müller, S.C., Becker, F.G., 2015. Forest expansion or fragmentation? Discriminating forest fragments from natural forest patches through patch structure and spatial context metrics. Austral Ecology, 40(1): 21-31.

Mert, A., Yalcinkaya, B., 2016. The relation of edge effect on some wild mammals in Burdur-Ağlasun (Turkey) district. Biological Diversity and Conservation, 9(2): 193-201.

Mert, A., Yalcinkaya, B., 2017. Relationship between some wild mammals and forest structural diversity parameters. Journal of Environmental Biology, 38(5): 879-884.

McGarigal, K., Cushman S. A., Neel, M. C. and Ene, E., 2002. FRAGSTATS: Spatial Pattern Analysis Program for Categorical Maps. Computer software program produced by the authors at the University of Massachusetts, Amherst. http://www.umass.edu/landeco/research/fragstats/fragsta ts.html. Accessed: 20.10.2018.

McGarigal, K., 2001. Landscape Metrics for Categorical Map Patterns, Lecture Notes. http://www.umass.edu /landeco/teaching/landscape_ecology/schedule/chapter9 _metrics.pdf. Accessed: 24.10.2018.

Morrison, J. A., Lubchansky, H. A., Mauck, K. E., McCartney, K. M., Dunn, B., 2007. Ecological comparison of two co-invasive species in eastern deciduous forests: Alliaria petiolata and Microstegium vimineum. The Journal of the Torrey Botanical Society, 134(1): 1-17.

Ode, Å., Hagerhall, C. M., Sang, N., 2010. Analysing visual landscape complexity: Theory and application. Landscape Research, 35(1): 111-131.

Paillet, Y., Bergès, L., Hjältén, J., Ódor, P., Avon, C., Bernhardt-Römermann, Bijlsma, R., Bruyn, L., Fuhr, M., Grandın, U., Kanka, R., Lundin, L., Luque, S., Magura, T., Matesanz, S., Mészáros, I., Sebastià, M., Schmidt, W., Standovár, T., Tóthmérész, B., Uotila, A., Valladares, F., Vellak, K., Virtanen, R., 2010. Biodiversity differences between managed and unmanaged forests: meta-analysis of species richness in Europe. Conservation biology, 24(1): 101-112. 
Plexida, S. G., Sfougaris, A. I., Ispikoudis, I. P., Papanastasis, V. P., 2014. Selecting landscape metrics as indicators of spatial heterogeneity-A comparison among Greek landscapes. International Journal of Applied Earth Observation and Geoinformation, 26: 26-35.

Ries, L., Sisk, T. D., 2010. What is an edge species? The implications of sensitivity to habitat edges. Oikos, 119(10): 1636-1642.

Šálek, M., Kreisinger, J., Sedláček, F., Albrecht, T., 2010. Do prey densities determine preferences of mammalian predators for habitat edges in an agricultural landscape? Landscape and Urban Planning, 98(2): 86-91.

Š́mová, P., Gdulová, K., 2012. Landscape indices behavior: a review of scale effects. Applied geography, 34:385394.

Tscharntke, T., Tylianakis, J. M., Rand, T. A., Didham, R. K., Fahrig, L., Batary, P., Bengtsson, J., Clough, Y., Crist, O.T., Dormann, F. C., Ewers, R. M., Fründ, J., Holt, R. D., Holzschuh, A., Klein, A. M., Kleijn, D., Kremen, C., Landis, D. A., Laurance, W., Lindenmayer,
D., Scherber, C., Sodhi, N., Steffan-Dewenter, I., Thies, C., van der Putten, W. H., Westphal, C., 2012. Landscape moderation of biodiversity patterns and processes-eight hypotheses. Biological Reviews, 87(3): 661-685.

Walz, U., 2011. Landscape structure, landscape metrics and biodiversity. Living reviews in landscape research, 5(3): $1-35$.

Wang, J., Xu, L., Wang, E., Huang, S., 2010. The potential landscape of genetic circuits imposes the arrow of time in stem cell differentiation. Biophysical journal, 99(1): 29-39.

Weyland, F., Laterra, P., 2014. Recreation potential assessment at large spatial scales: A method based in the ecosystem services approach and landscape metrics. Ecological indicators, 39: 34-43.

Verburg, P. H., Neumann, K., Nol, L., 2011. Challenges in using land use and land cover data for global change studies. Global Change Biology, 17(2): 974-989. 